\section{ABSCESS OF THE SPINAL CORD} WITII REPORT OF A CASE*

\section{CHARLES W. HITCHCOCK, M.D. Attending Neurologist, Harper Hospital DETROIT}

$\Lambda$ bscess of the spinal cord is so rarc a condition, presents so irregular a clinical picture, and involves such interesting and difficult problems in diagnosis that this case has seemed to be descrving of full report:

A. J., man, teamster, was admitted to Harper Hospital, Sept. 28, 1916, complaining of at motor impairment of the left leg of twelve days' duration. The personal and family history were negative. Though five children had clied at birth, only one living two hours, venercal discase was lenied and the patient's Wasscrmann test was negalive.

He had been a pretty steady user of alcohol, ordinarily drinking four or five bottles of beer claily, and on the Saturday night, twelve days prior to his admission, he had drunk more heavily than usual. About $10 \mathrm{p}$. $\mathrm{m}$. of this clay, he experienced a numbness in his left leg, and he could walk only with difficulty. The next day, he felt better but he limped for several days and then complained of pain in the left abdominal region. From then on, the motor impairment of the left leg had been progressively worse, ncessitating a sidewise dragging of the left foot in his attempts to walk. The aldominal pain on admission was present only when lie sat up or moved, and did not seem to be aculc. Bladder control had been difficult for three days, and there was slight dribbling of the urine. Examination disclosed some pyorrhea alvcolaris and also suppurating lesions of the hands which, he said, had followed the lite of a horse. There were no enlarged glands, and the epitrochlears were not palpable. The chest and the alydomen were practically negative, as also were tests of special sensc. Sensory examination disclosed no changes in the arms, but over the abdomen were indefinite areas in which pain sense secmed diminished, and over the legs also pain sense was less acute than normal. Tactile sense was unimpaired. There was almost complete loss of motor power of the left leg, the right leg was umimpaired, and no other motor symptoms were noticed.

The arm reflexes scemed increased in activity, the knee jerks and the Aclilles jerks werc hyperactive, and clonus was easily elicited on both sides. There was no Kernig sign, there was a suggestion of a Babinski, and there was no ataxia.

The blood count revealed: white hlood cells, 12,400; red blood cells, 5,120,000; hemoglobin, 90 per cent. The lesions of the hands yielded a culture of a staphylococetus.

September 30, numbness of the right leg complained of, and reflexes on looth sides were elicited only with difficulty, response being very slight.

October 1, there was quite complete paralysis of the right leg as well as the left, and reflex response was harclly perceptible.

October 3 , the reflexes were still less, there being a questionalule clonic response at the left ankle, complete naraplegia, and there was analgesia from the level of the twelfth dorsal vertebra down. Tactile sense of the lower extremities was good, showing well marked dissociation of sensation. $\Lambda$ bdominal, cremasteric, knce and ankle reflexes were absent. The pupils were ec(ual and stiffly responsive. Rocutgenologic examinations, October 3 and 7 , were negative. The temperature curve was such as to point to the existence of some infectious process.

The analgesia remained for scveral days at the level of the twelffl dorsal vertebra, but later slowly ascended. The bladder was involved in the motor paralysis, and frequent catheterization was necessary. The blood count and the clinical course of the disease pointed to the existence of an infection

- Rend before the Detroit Socicty of Neurology and Psychiatry, Feb. 1, 1917 .

* On account of lack of space, this article has becn alsbreviated in THE JOURNAL by omission of a review of the literilure. This will be included in the reprints, a copy of which may be obtitined on applical. tion to the author. involving the cord, and it was hoped that surgical interference might possibly reach and drain the infected focus.

Octoher 7, laminectomy was done by Dr. A. D. McAlpine, the fifth, sixth, and seventh dorsal laminac being removed, the dura was incised, and the region carefully explored above and below but with negative results. The cord itself was not incised or explored.

October 9, there was ancsthesia to the level of the nipples, and the arm reflexes seemed less active than normal. From this time on, there was little clinical change aside from gradual failure. Spinal puncture had yielded a turbid fuid, and from this a staphylococcus had been grown in culture.

There was progressive failure, a terminal bronchopneumonia, and cystitis. The patient died, 3:45 p. m., Octoher 25 . lumbar puncture was at once repeated, and cultures from the spinal fluid yiclded Staphylococcus albus.

Necropsy was done at $5 \mathrm{p}$. m. by Dr. Plinn F. Morse, pathologist. The body was slightly cmaciated, but generally well nourished, still warm, showing a large gangrenous slough in the gluteal region, and the right heel threateningly black from trophic disturbance. The spinous processes and laminae of all the vertebrae werc removed and the cord detached from below upward to the foramen magnum.

The cord, sectioned from above downward, showed macroscopically nothing of especial interest in the cervical regiom, but in the upper dorsal region, the anterior horns appeared increasingly injected as section proceeded downward. The lower seven inches of the cord showed the central portion filled with thick, crcamy pus, this accumulation being broalce in area as we procecled downward-the tisstie of the cord being much encroaclucd on toward its terminus.

The results of further cxamination are given in the pathologist's report (by Dr. Morse):

"Sections of the cord taken from the dorsal region show complete degeneration of the posterior coltumns. Fxtreme clema at the cutrance root zone, with a necrosis of the axial portion of the posterior nerve root. The blood vessels of the gray matter show marked round-cell infiltration. The rest of the cord at this level is fairly normal, except for edema. Sections taken at the level of greatest softening show complete disintegration of all the columns of white matter; complete disappcarance of the anterior horn cells of the gray matter and, in general, complete necrosis of the cord, as a whole. The posterior root ganglia in some arcas show focal necrosis of the centers, and in regions contiguuts to this, we find marked round-cell infiltration of the pia mater."

\section{COM MENT}

Difficultics of diagnosis were not few in this case. The rapid onset of the motor and sensory paralysis immediatcly following alcoholic excess at first suggested the possibility of a toxic cause, but later the clinical aspects of the case were such as conclusively to prove that the process was an infectious one. The dissociation syndrome, which persisted for several days, pointed to the probable involvement of the central portion of the cord, but this symptom had disappeared with further encroachment on the other tissues of the cord. The laminectomy still left us in the dark, the operating surgcon not decming it wise to attempt cven careful exploration of the cord itself. Several diagnoses were hazarded, but the clinical history secmed to point to an infection of the cord, which had at first encroached on the posterior columins and then involved a transverse myclitis at the seventl dorsal segment.

$\Lambda s$ to the possibility of reaching and draining such an abscess, Elsberg under recent date writes me:

Too bad that the cord was not aspirated, for the aloscess could surely have been found and drained. I fecl positive that the time will come when this will literally be done in these rare cases. Of course, there is no reason why an abscess of the cord could not be satisfactorily drained just as well as an alsscess of the brain. 
Abscess of the cord is thus shown to be of rare occurrence and of irregular clinical picture, this depending largely on the level and cxtent of the myelitic process caused by the infection and the amount of destruction of cord tissue involved.

The case reported secms clearly one of metastasis from the suppurative lesions on the hands, a staphylococcic infection following the bite of a horse.

$1501^{\circ}$ David Whitney Building.

\section{UNTOWARD RESULTS OF PROPHYLACTIC TYPHOID IMMUNIZATION}

\section{WILLIAM LINTZ, M.D.}

Professor of Bacteriology, Long Island College IIospital; Associatc Visiting l'hysician, Brooklyn Jewish Hospital BROOKLYN

In view of the great frequency with which typhoid vaccination is nowalays performed, and the comparative ease and safety of the procedure, I believe it is wise to bear in mind that untoward results may follow typhoid inoculation; as in the case herewith reported, with the idea, not of paralyzing activities in this direction, but that it is necessary to take proper precautions with patients who are inoculated with typhoid vaccine. I believe that patients who receive the vaccine should be instructed to go home and not to their vocations, where the sudden appearance of certain mental and nervous symptoms would jeopardize their lives.

History.-W. S., man, aged 24, was one of thirty-three senior students who presented themselves on the morning of Oct. 28, 1916, for the routine typhoid vaccination. He received the same as the other students, 500 million bacilli of the U. S. army strain, nonsensitized, and prepared in the usual manner. The same vaccine from the same bottle and the same teclinic were employed with this student as in the other thirty-two. The thirty-two students presented the usual signs and symptoms of reactions after typhoid vaccination. The paticnt, on the other hand, presented the following rather unusual symptoms :

Twenty minutes after the subcutaneous injection of the vaccine he felt weak all over the body, especially in the lower extremities. A sensation of chilliness and a clull heaclacle set in. These symptoms were progressively becoming more severe, until one hour after the injection the patient began to shake violently over the whole body, and he lad an unbearalle throbbing headache. Then the rather unusual symptom of continuous vomiting set in. The vomitus was at first slimy mucus, and then mucus and blood, which was bright red. The soreness all over the hody became extreme and the joints excedingly painful. The temperature was 103 , pulse 100 (normal 60). The vomiting, the painful joints and soreness all over the body persived for forty-eight lours. He remained apathetic for forty-eigh: hours, during which time anorexia and polydipsia were marked. The stools w:re yellow and watery. The urine was red and contained biood. At the height of the illness the patient was in extreme collapse The temperature continued high for seventy-two hours with slight morning remissions; it was about 101 in the afternoon. The pulse ranged from 90 to 96 . There was no nose bleed. On the second day the spleen became palpable, and on deep inspiration was felt one finger's breadth below the free costal margin. The liver edge was palpable below the costal margin. The glands in the neck, axilla and groin were decidedly enlarged; those in the axilla were very tender. The convalesence lasted one week, the patient complaining of dull headache and severe pain in the bones of the legs.

The local reaction was very slight and consisted of redness and slight tenderness. The liver, spleen and lymphatic glands remained enlarged for one week and then gradually subsided.
If the patient had suffered from a regular course of typhoid he could not have fallen away more or looked worse. $\mathrm{He}$ was excedingly fecble.

Laboratory Findings.-In the urine there were large quantitics of blood. The diazoreaction was negative; four tests were made; the first one on the fourth day after the vaccination. There were no other pathologic findings.

Blood examination before the vaccimation revealed: total red cells, 4,900,000; total white cells, 7,800; differential count: polymorphonuclears, 74 per cent.; small lymphocytes, 20 per cent.; large lymphocytes, 3 per cent.; transitionals, 2 per cent.; cosinophils, 1 per cent. After vaccination (four days following injection): total red cells, 4,700,000; total white cells, 7,600 ;-differential count: polymorphonuclears, 65 per cent.; small lymphocytes, 32 per cent. ; large lymphocytes, 3 per cent.

Ihe Gruber-Widal test on the fourth day after vaccination revealed loss of motility but no clumping.

In view of the severity of the reaction, the presence of blood in the vomitus and urine, and the general collapse which followed, it is hardly necessary for me to say that I did not give the patient the second and third injections:

The previous history of the patient was absolutely negative. He never had typhoid or any other disease. He is not subject to hives or any other rashes. He does not suffer from asthma or hay-fever. He does not present symptoms of anaphylaxis when around horses, cats or dogs. He is not sickened by cating shellfish or any other food with the exception of ice cream, which even in minute amounts sickens him, and the mere smell of it natuseates him. He has never before received typhoid vaccine. From the foregoing it is therefore difficult to determine what has sensitized him against the protein of the typhoid bacillus. I do not doubt for a moment that sensitization or anaphylaxis was responsible for the symptoms.

\section{ENDEMIC INDEX OF MALARIA IN THE NORTHERN SACRAMENTO VAL- LEY, CALIFORNIA}

$$
\text { F. L. KELLY, M.D. }
$$

J. C. GEIGER, M.D.

Assistant Epidemiologist and Assistant Director, respectively, Bureau of Communicable Discases, California State Board of Health BERKLLEY, CALHF,

Although for many years nalaria has been known to be prevalent in the great central valleys of California and the foothills adjacent to them, no systematic attempt has been made to study the types and endemicity of the disease prior to 1915 . However, W. B. Herms, ${ }^{1}$ associate professor of parasitology in the University of California and consulting parasitologist of the California State Board of Health, has done a large amount of educational and mosquito control work. Early in 1915, Dr. K. F. Meyer ${ }^{2}$ and Dr. E. L. Waller, associate professors of tropical medicine in the George Williams Hooper Foundation for Medical Research, began an investigation in order to determine the endemicity of malaria and the types of mosquitoes involved. $\Lambda$ fter several weeks this investigation was discontinued.

In September, 1915, after conferring with Professor Herms, we sulbmitted to Dr. W. A. Sawyer, secretary

1. Herms, W. B.: Malaria, Cause and Control, New York, the Macmillan Company, 1913; Successful Methods of Attack on Malaria in Millan Company, 1913 ; Successfti Methods of At

2. Meyer, K. F.: Sources of Malaria in California, Tr. Common. wealth Club of California, San liancisco, 1916, 11, 22. 